\title{
Effect of the economic crisis on the use of health and home care services among Spanish COPD patients
}

This article was published in the following Dove Press journal: International Journal of COPD

\author{
Javier de Miguel-Diez' \\ Ana Lopez-de-Andres ${ }^{2}$ \\ Valentin Herandez-Barrera ${ }^{2}$ \\ Isabel Jimenez-Trujillo ${ }^{2}$ \\ Luis Puente-Maestu' \\ Alicia Cerezo-Lajas' \\ Rodrigo Jimenez-Garcia ${ }^{2}$ \\ 'Respiratory Department, Hospital \\ General Universitario Gregorio \\ Marañón, Facultad de Medicina, \\ Universidad Complutense de Madrid \\ (UCM), Instituto de Investigación \\ Sanitaria Gregorio Marañón (liSGM), \\ Madrid, Spain; ${ }^{2}$ Preventive Medicine \\ and Public Health Teaching and \\ Research Unit, Health Sciences \\ Faculty, Universidad Rey Juan Carlos, \\ Alcorcón, Madrid, Spain
}

Background: Chronic obstructive pulmonary disease (COPD) is a major cause of disability and death worldwide. Consequently, COPD patients are frequent users of health and social resources. Therefore, they are highly vulnerable to decreases in investment in healthcare services. We aimed to describe the utilization of health and home care services among Spanish COPD patients during the economic crisis to identify factors independently associated with changes in the utilization of these services and to study the time trends from 2009 to 2014.

Methods: We used data from the European Health Interview Surveys for Spain (EHSS) conducted between 2009/2010 $(n=22,188)$ and $2014(n=22,842)$. We included responses from adults with COPD aged 40 years or over. Dependent variables included self-reported hospitalizations during the previous year, general practitioner (GP) visits during the last 4 weeks, other health care services used during the previous year (nursing, rehabilitation, and psychological services), and home care services use during the previous year. Independent variables included demographic and socioeconomic characteristics, health status variables, and lifestyles.

Results: We identified 1,328 and 1,008 COPD patients from EHSS 2009 and EHSS 2014, respectively. We observed a significant increase in non-GP services use $(30.6 \%$ in 2009 vs $39.11 \%$ in 2014; $p<0.001$ ). No changes were found for hospitalizations, GP visits, and home care services use over time. Multivariable models showed that associated factors with a higher use included any chronic comorbidity and worse self-rated health. Physical activity was a strong predictor of fewer hospitalizations and less home care service use. Female sex was associated with significantly fewer hospitalizations (OR 0.72; 95\% CI 0.58-0.89).

Conclusion: We found an increase in the use of non-GP services (nursing, rehabilitation, and psychological) but not in other health and home care services. The only differences in hospitalizations were observed according to sex. Therefore, the effect of the economic crisis, if any, seems to have been of small magnitude.

Keywords: COPD, healthcare services, population-based, time trends, survey, economic crisis

\section{Background}

Chronic obstructive pulmonary disease (COPD) represents an important health problem, being a major cause of disability and death worldwide. ${ }^{1}$ According to the Burden of Obstructive Lung Disease group, the average global COPD prevalence was $10.1 \%$, with wide variations across the participating countries. ${ }^{2}$ In addition, COPD becomes more common with age, and it has been shown to have a substantial impact on health outcomes, including healthcare resource use. ${ }^{3,4}$ Consequently, the management of COPD is a significant and costly issue. ${ }^{5}$ 
Regardless of severity, COPD patients often require healthcare assistance, in terms of not only hospitalizations but also scheduled and non-scheduled office visits and emergency visits. ${ }^{6}$ These individuals may also need health services for comorbid conditions, which have an important impact on functions and the quality of life..$^{7-9}$ Other factors that can influence higher healthcare resource utilization in patients with COPD are reduced physical activity, respiratory failure and systemic inflammation. ${ }^{6}$

In Spain, there has been a reduction in healthcare services because of the austerity measures that have been imposed during the economic crisis of 2008, and out-of-pocket payments have been implemented for some services. ${ }^{10}$ These policies probably did not affect the whole population in the same way; vulnerable groups, due to their worse health conditions, can be at greater risk of exclusion from social and healthcare services.

Since COPD patients are frequent users of health and social resources, a better understanding of the patterns of use of these services during the economic crisis is fundamental for the establishment of health plans geared toward the proper management of COPD in these patients and the reduction of overall costs of this disease. ${ }^{5}$ However, data on the use of health and social services during the economic crisis among Spanish COPD patients, associated factors and time trends are lacking.

The main objectives of this study were (a) to describe the utilization of health and home care services among Spanish patients with COPD according to sex during the economic crisis (2009 to 2014); (b) to identify which factors, including sociodemographic, characteristics, health-related and lifestyle variables, were independently associated with changes in the utilization of health and home care services according to sex; and (c) to study the time trends, from 2009 to 2014 , in the use of health and home care and social services among COPD patients, both women and men.

\section{Methods}

\section{Study design, setting, and participants}

We conducted a cross-sectional study using individualized data taken from the European Health Interview Surveys for Spain (EHSS) conducted in 2009/2010 $(\mathrm{n}=22,188)$ and 2014 $(n=22,842)$. These surveys covered a representative sample of non-institutionalized adults (age 15 years or over) residing in main family dwellings (households) in Spain. Information was collected in home-based, computer-assisted, personal interviews conducted from April 2009 to March 2010 for the EHSS 2009/2010 and from January to December 2014 for the EHSS 2014. Details on the survey methodology can be found elsewhere. ${ }^{11,12}$ The interviews were conducted in Spanish. The translation was done by the Spanish Ministry of Health.

We selected those subjects aged 40 years or over from the EHSS 2009 and EHSS 2014. To identify those with COPD in our study, we included all subjects if they answered affirmatively to the following question: "Has your doctor told you that you are currently suffering from chronic bronchitis, emphysema, or COPD?"

\section{Study variables and data sources/ measurement}

The variables included in our study were based on questions identically worded in both surveys. The questions used to assess the use of healthcare services were as follows: (a) "Have you been in the hospital as an inpatient, that is overnight or longer, in the last year?", with two possible answers, "Yes" or "No"; (b) "Have you visited a general practitioner (GP) for any medical condition in the last 4 weeks?", with two possible answers, "Yes" or "No"; and (c) "Have you used nurse care services/rehabilitative care services/psychological care services in the last year?", in relation to which we created the variable "Non-GP services use", which is considered affirmative if one or more of the nurse care services and/or rehabilitative care services and/or psychological care services were used.

Information regarding the use of home services in the last year included five questions: (a) "Have you used home care service provided by a nurse or midwife?"; (b) "Have you received home help for housework or for looking after elderly people in your home?"; (c) "Have you received meals on wheels?"; (d) "Have you received any transport service?"; and (e) "Have you received any other home care services?"; with two possible answers, "Yes" or "No", for each question. We considered receivers of home care services as those persons who answered "Yes" to any of the previous five questions and not those who answered negatively to all of them. ${ }^{11,12}$ All those patients who answered "I do not know" or refused to answer were excluded from the analysis of that question.

We analyzed the following independent variables: (a) demographic and socioeconomic characteristics, including age, gender, educational level, monthly income and if the person interviewed was living with a partner (yes/no); (b) health status, including self-perceived health (very good/good vs fair/poor/very poor), self-reported physician diagnosed chronic conditions (asthma, coronary disease, myocardial infarction, angina, cerebral infarction, cerebral hemorrhage, cerebral embolism and cancer), mental disorders (anxiety and depression) and pain; and (c) lifestyles including 
self-reported body mass index (BMI), physical exercise, tobacco use and alcohol consumption. The questions used to create these variables can be found elsewhere, and the categories are shown in Table $1 .{ }^{13,14}$

\section{Statistical methods}

The distribution according to the study variables was described and compared for each EHSS and for women and men. We used proportion and means with standard deviations

Table I Distribution of hospitalization admissions in COPD subjects according to demographic and socioeconomic variables, health status, and lifestyles in the EHSS, 2009 and 2014

\begin{tabular}{|c|c|c|c|c|}
\hline \multirow[t]{2}{*}{ Variables } & \multicolumn{2}{|l|}{2009} & \multicolumn{2}{|l|}{2014} \\
\hline & Men, n (\%) & Women, n (\%) & Men, n (\%) & Women, n (\%) \\
\hline \multicolumn{5}{|l|}{ Age groups ${ }^{A, B, C, D}$} \\
\hline $40-54$ years & $12(10.34)$ & $19(14.07)$ & $10(14.08)$ & $10(12.82)$ \\
\hline $55-69$ years & $40(22.1)$ & $31(14.9)$ & $31(22.63)$ & $35(21.34)$ \\
\hline 70 years or over ${ }^{a}$ & $103(34.56)$ & $83(26.18)$ & 77 (29.39) & $77(29.96)$ \\
\hline \multicolumn{5}{|l|}{ Educational level ${ }^{\mathrm{A}}$} \\
\hline No formal study/primary ${ }^{a}$ & $126(29.93)$ & $101(21.04)$ & 81 (27) & 9I (26.53) \\
\hline Secondary & $17(16.04)$ & $26(19.12)$ & $22(20.37)$ & 21 (20.59) \\
\hline Higher education & $12(17.65)$ & $6(13.64)$ & $15(24.19)$ & $10(18.52)$ \\
\hline \multicolumn{5}{|l|}{ Monthly income $e^{D}$} \\
\hline$<850$ Euros $^{\mathrm{b}}$ & $47(29.56)$ & $48(21.24)$ & $43(25.75)$ & $64(30.33)$ \\
\hline $850-1,400$ Euros & $39(23.78)$ & $29(17.9)$ & $33(33.67)$ & $25(27.47)$ \\
\hline$>1,400$ Euros & $48(24.12)$ & $38(20.54)$ & $31(22.63)$ & $18(16.07)$ \\
\hline \multicolumn{5}{|l|}{ Living with partner } \\
\hline Yes & $100(24.15)$ & $54(17.25)$ & $87(26.61)$ & $43(20.77)$ \\
\hline No & 55 (30.39) & 79 (22.77) & 31 (2I.68) & $79(27.05)$ \\
\hline \multicolumn{5}{|l|}{ Self-rated health ${ }^{A, B, C, D}$} \\
\hline Very good/good & $19(10.92)$ & II (7.24) & $13(9.77)$ & $12(10.91)$ \\
\hline Fair/poor/very poor ${ }^{a}$ & $136(32.3)$ & $122(24.02)$ & $105(31.16)$ & $110(28.28)$ \\
\hline \multicolumn{5}{|l|}{ Any chronic comorbidity $\mathrm{A}, \mathrm{B}, \mathrm{C}, \mathrm{D}$} \\
\hline No & $42(17.14)$ & $31(12.4)$ & $2 \mid(|3.2|)$ & $28(I 5.56)$ \\
\hline$Y_{e s}^{a}$ & $113(32.29)$ & $102(24.88)$ & 97 (31.19) & 94 (29.47) \\
\hline \multicolumn{5}{|l|}{ High blood pressure ${ }^{\mathrm{B}, \mathrm{D}}$} \\
\hline $\mathrm{No}^{\mathrm{a}}$ & 74 (22.98) & 54 (I5.98) & 61 (24.4) & 48 (19.59) \\
\hline Yes & 81 (29.67) & $79(24.53)$ & $57(25.91)$ & $74(29.13)$ \\
\hline \multicolumn{5}{|l|}{ Mental disorder ${ }^{\mathrm{A}, \mathrm{B}}$} \\
\hline $\mathrm{No}^{\mathrm{a}}$ & $122(24.02)$ & $69(16.79)$ & $97(24.87)$ & $65(22.03)$ \\
\hline$Y_{e s}^{a}$ & $33(37.93)$ & $64(25.7)$ & $21(26.25)$ & $57(27.94)$ \\
\hline \multicolumn{5}{|l|}{$\operatorname{Pain}^{\mathrm{A}, \mathrm{B}, \mathrm{C}}$} \\
\hline No & $49(18.35)$ & $22(13.84)$ & $30(19.23)$ & $15(19.74)$ \\
\hline$Y_{e s}{ }^{a}$ & $106(32.32)$ & $111(22.16)$ & $88(28.03)$ & $107(25.3)$ \\
\hline \multicolumn{5}{|l|}{ Body mass index ${ }^{A, D}$} \\
\hline$<25 \mathrm{~kg} / \mathrm{m}^{2, a}$ & $50(33.33)$ & $30(17.14)$ & $37(26.43)$ & $26(19.12)$ \\
\hline $25-30 \mathrm{~kg} / \mathrm{m}^{2}$ & $53(21.46)$ & $34(17.62)$ & $43(22.05)$ & $37(22.56)$ \\
\hline$\geq 30 \mathrm{~kg} / \mathrm{m}^{2}$ & $35(23.65)$ & $43(23.63)$ & $34(28.81)$ & 47 (32.19) \\
\hline \multicolumn{5}{|l|}{ Physical exercise ${ }^{A, B, C}$} \\
\hline $0-3$ days per week ${ }^{\mathrm{a}}$ & $75(35.21)$ & $74(23.72)$ & 72 (34.29) & $65(27.31)$ \\
\hline 4-7 days per week & $80(20.94)$ & $59(16.95)$ & 46 (I7.69) & $57(21.84)$ \\
\hline \multicolumn{5}{|l|}{ Tobacco use $e^{A, C}$} \\
\hline Current smoker & $30(18.18)$ & 14 (I4.89) & $20(16.67)$ & $17(21.25)$ \\
\hline Ex-smoker & $80(29.52)$ & $2 I(25.6 I)$ & $86(30.07)$ & $21(26.25)$ \\
\hline Never smoker ${ }^{b}$ & 21 (20.79) & $80(18.48)$ & $12(19.05)$ & $84(24.78)$ \\
\hline \multicolumn{5}{|l|}{ Alcohol consumption ${ }^{A, B, C, D}$} \\
\hline $\mathrm{No}^{\mathrm{a}}$ & $89(29.67)$ & $119(21.6)$ & $66(30.84)$ & $102(27.06)$ \\
\hline$Y_{e s}{ }^{a}$ & $66(22.37)$ & $14(12.84)$ & $52(20.3 \mathrm{I})$ & $20(16.39)$ \\
\hline Total $^{\mathrm{a}}$ & $155(26.05)$ & $133(20.15)$ & II 18 (25.1I) & $122(24.45)$ \\
\hline
\end{tabular}

Notes: ${ }^{A}$ Significant differences $(p<0.05)$ between the variable and hospitalization among COPD men in 2009. ${ }^{B}$ Significant differences $(p<0.05)$ between the variable and hospitalization among COPD women in 2009. CSignificant differences $(p<0.05)$ between the variable and hospitalization among COPD men in 2014. ${ }^{D}$ Significant differences $(p<0.05)$ between the variable and hospitalization among COPD women in 2014. ${ }^{2}$ Significant differences $(p<0.05)$ between COPD men and COPD women for hospitalizations in 2009. bSignificant differences $(p<0.05)$ between hospitalizations in COPD women in 2009 and hospitalizations in COPD women in 2014.

Abbreviations: COPD, chronic obstructive pulmonary disease; EHSS, European Health Interview Surveys for Spain. 
as descriptive statistics. We estimated the use of health and home care services variables in each of the two surveys. To perform bivariate comparisons, we used the chi-squared test for categorical variables and two-sided independent $t$-tests for continuous variables.

We conducted multivariable logistic regression models for each dependent variable (hospitalization, GP visit, use of home care services, use of other health care services) to identify those study variables independently associated with the use of these services. We conducted the multivariable models using each EHSS and a database with both EHSS joined to assess the time trend from 2009 to 2014. The multivariable analyses were performed including those variables that were statistically significant in the bivariate analysis and those which, although they did not reach the point of statistical significance, were of interest from an epidemiological and healthcare point of view. The results of the regression models are shown as OR with $95 \%$ CI. We checked for interactions in the models.

A sensitivity analysis was performed to see if there was an overall difference between the two years studied in addition to the effect of changes in the income overtime. To do so, we conducted the multivariable model with and without the variable "Monthly income" included.

Estimations were made using the STATA program, and significance was set at two-tailed $\alpha<0.05$.

\section{Ethical aspects}

This study was conducted using an anonymous public access dataset, and confidentiality was maintained at all times. In accordance with Spanish legislation, it was not necessary to obtain the approval of an ethics committee. The Spanish legislation says, "All studies of observational type must be submitted for evaluation of a Clinical Research Ethics Committee, with the exception of those studies that are conducted using existing information that does not include personal data." 15 The EHSSs used in our investigation are free and public access data that have no personal data of the subjects interviewed, which makes it impossible to identify them. These databases can be downloaded freely from the Spanish National Statistics Institute. ${ }^{16}$

\section{Results}

The prevalence of COPD among subjects aged 40 years or over was $7.59 \%(n=1,328 / 17,489)$ for the EHSS 2009 and $5.38 \%(\mathrm{n}=1,008 / 18,724)$ for the EHSS $2014(p<0.01)$. The distribution of the study populations according to demographic and socioeconomic variables, health status, lifestyles and healthcare resource use are shown in Table S1.
In general, COPD Spanish subjects were older, had improved their educational level and had significantly lower monthly income over the previous 5 years. The self-rated health status and the frequency of mental disorders did not change in that period; however, COPD subjects reported more pain in the last survey $(66.06 \%$ in 2009 vs $76.06 \%$ in 2014; $p<0.001$ ). In 2014, COPD sufferers also showed significantly higher figures of alcohol consumption and tobacco use. Regarding the use of healthcare resources, the visits to the GP did not change from 2009 to 2014 (56.33\% vs 56.04\%; $p=0.888$ ); however, the prevalence of non-GP service use in the previous 4 weeks increased over time $(30.6 \%$ in 2009 vs $39.11 \%$ in $2014 ; p<0.001)$. No changes were found for hospitalizations $(22.95 \%$ vs $24.77 \%$; $p=0.317)$ or home care services $(16.1 \%$ vs $18.47 \%$; $p=0.140)$.

Table 1 shows the distribution of hospital admissions in COPD subjects according to demographic and socioeconomic variables, health status and lifestyles. In both surveys, we found that subjects (men and women) with fair/poor/ very poor self-rated health and any chronic comorbidity had significantly higher frequency of hospitalization. In 2009, the hospitalizations were higher in men. They were also significantly more frequent in older age and in subjects with mental disorders, pain in the last 4 weeks, not practitioners of physical exercise, ex-smokers, and non-alcohol consumers. In 2014, hospitalizations were also higher in older age, but no significant differences were found between genders. On the other hand, the prevalence of hospitalizations did not change significantly over the study period in men or women.

Table 2 shows the distribution of GP visits in the last 4 weeks among COPD subjects. In both surveys, we found that subjects, men and women, with fair/poor/very poor self-rated health, and any chronic comorbidity and pain in the last 4 weeks, had significantly higher frequencies of GP visits. In 2009, GP visits were higher in older age and in women. In men, they were significantly more frequent in subjects with lower educational levels, living with a partner and with no alcohol consumption, while in women, they were also higher in those with lower monthly incomes, mental disorders and no practice of physical exercise. In 2014, GP visits were more frequent in older age and in subjects with high blood pressure and with no alcohol consumption in both genders. When we compared men and women, no significant differences were found in the use of GP visits from 2009 to 2014.

Table 3 shows the distribution of non-GP service use in COPD subjects. In both surveys, we found that men and women with mental disorders had significantly higher frequency of use. In 2009, non-GP service use in men was 
Table 2 Distribution of general practitioner visit in COPD subjects according to demographic and socioeconomic variables, health status, and lifestyles in the EHSS, 2009 and 2014

\begin{tabular}{|c|c|c|c|c|}
\hline \multirow[t]{2}{*}{ Variables } & \multicolumn{2}{|l|}{2009} & \multicolumn{2}{|l|}{2014} \\
\hline & Men, n (\%) & Women, n (\%) & Men, n (\%) & Women, n (\%) \\
\hline \multicolumn{5}{|l|}{ Age groups ${ }^{A, B, C, D}$} \\
\hline $40-54$ years $^{\mathrm{a}}$ & $34(29.31)$ & $60(44.44)$ & $30(42.25)$ & $35(44.87)$ \\
\hline $55-69$ years $^{b}$ & $92(50.83)$ & $119(57.21)$ & $69(50.36)$ & $101(61.59)$ \\
\hline 70 years or over & I85 (62.08) & $217(68.45)$ & $159(60.69)$ & 149 (57.98) \\
\hline \multicolumn{5}{|l|}{ Educational level ${ }^{A, B, C}$} \\
\hline No formal study/primary & $238(56.53)$ & $311(64.79)$ & $179(59.67)$ & $202(58.89)$ \\
\hline Secondary & $47(44.34)$ & $66(48.53)$ & $48(44.44)$ & $58(56.86)$ \\
\hline Higher education $^{d}$ & $26(38.24)$ & $19(43.18)$ & $31(50)$ & $25(46.3)$ \\
\hline \multicolumn{5}{|l|}{ Monthly income $e^{B, D}$} \\
\hline$<850$ Euros & $85(53.46)$ & $142(62.83)$ & $99(59.28)$ & I33 (63.03) \\
\hline $850-1,400$ Euros & $96(58.54)$ & $105(64.81)$ & $63(64.29)$ & $57(62.64)$ \\
\hline$>1,400$ Euros & $94(47.24)$ & $98(52.97)$ & $70(51.09)$ & $49(43.75)$ \\
\hline \multicolumn{5}{|l|}{ Living with partner ${ }^{A}$} \\
\hline Yes & $228(55.07)$ & $192(61.34)$ & $180(55.05)$ & II 8 (57) \\
\hline $\mathrm{No}^{\mathrm{a}}$ & $83(45.86)$ & 204 (58.79) & $78(54.55)$ & $167(57.19)$ \\
\hline \multicolumn{5}{|l|}{ Self-rated health ${ }^{A, B, C, D}$} \\
\hline Very good/good & $63(36.21)$ & $54(35.53)$ & $58(43.61)$ & $44(40)$ \\
\hline Fair/poor/very poor ${ }^{a}$ & $248(58.91)$ & $342(67.32)$ & $200(59.35)$ & $24 I(6 I .95)$ \\
\hline \multicolumn{5}{|l|}{ Any chronic comorbidity $A, B, C, D$} \\
\hline No & $100(40.82)$ & $120(48)$ & $72(45.28)$ & $87(48.33)$ \\
\hline Yes $^{\mathrm{a}}$ & $211(60.29)$ & $276(67.32)$ & $186(59.8 \mid)$ & $198(62.07)$ \\
\hline \multicolumn{5}{|l|}{ High blood pressure ${ }^{A, B, C, D}$} \\
\hline $\mathrm{No}^{\mathrm{a}}$ & $139(43.17)$ & $|8|(53.55)$ & $119(47.6)$ & $124(50.61)$ \\
\hline Yes & $172(63)$ & $215(66.77)$ & $139(63.18)$ & I6I (63.39) \\
\hline \multicolumn{5}{|l|}{ Mental disorder ${ }^{\mathrm{B}, \mathrm{D}}$} \\
\hline No & $258(50.79)$ & $216(52.55)$ & $211(54.1)$ & $154(52.2)$ \\
\hline Yes $^{\mathrm{a}}$ & $53(60.92)$ & $180(72.29)$ & $47(58.75)$ & I3I (64.22) \\
\hline \multicolumn{5}{|l|}{ Pain $A, B, C, D$} \\
\hline No & $106(39.7)$ & $64(40.25)$ & $69(44.23)$ & $27(35.53)$ \\
\hline Yes & $205(62.5)$ & $332(66.27)$ & $189(60.19)$ & $258(60.99)$ \\
\hline \multicolumn{5}{|l|}{ Body mass index } \\
\hline$<25 \mathrm{~kg} / \mathrm{m}^{2}$ & $86(57.33)$ & I0I (57.7I) & $65(46.43)$ & $74(54.4 I)$ \\
\hline $25-30 \mathrm{~kg} / \mathrm{m}^{2, a}$ & $125(50.6 \mid)$ & $118(61.14)$ & $116(59.49)$ & $95(57.93)$ \\
\hline$\geq 30 \mathrm{~kg} / \mathrm{m}^{2, a}$ & $75(50.68)$ & $112(61.54)$ & $67(56.78)$ & $90(61.64)$ \\
\hline \multicolumn{5}{|l|}{ Physical exercise $\mathrm{B}^{\mathrm{B}, \mathrm{C}}$} \\
\hline $0-3$ days per week & $|2|(56.8 I)$ & $202(64.74)$ & $128(60.95)$ & $142(59.66)$ \\
\hline 4-7 days per week & $190(49.74)$ & $194(55.75)$ & $130(50)$ & I 43 (54.79) \\
\hline \multicolumn{5}{|l|}{ Tobacco use ${ }^{B}$} \\
\hline Current smoker & 77 (46.67) & $5 \mathrm{I}(54.26)$ & $58(48.33)$ & $38(47.5)$ \\
\hline Ex-smoker ${ }^{c}$ & I 47 (54.24) & $39(47.56)$ & I 67 (58.39) & $50(62.5)$ \\
\hline Never smoker & $54(53.47)$ & $270(62.36)$ & $32(50.79)$ & $197(58.11)$ \\
\hline \multicolumn{5}{|l|}{ Alcohol consumption ${ }^{\mathrm{A}, \mathrm{B}, \mathrm{C}, \mathrm{D}}$} \\
\hline No & I77 (59) & $342(62.07)$ & $142(66.36)$ & $23 \mid(6 \mid .27)$ \\
\hline Yes & I 34 (45.42) & $54(49.54)$ & $116(45.31)$ & $54(44.26)$ \\
\hline Total $^{\mathrm{a}}$ & $311(52.27)$ & $396(60)$ & $258(54.89)$ & $285(57.11)$ \\
\hline
\end{tabular}

Notes: ASignificant differences $(p<0.05)$ between the variable and general practitioner visit among COPD men in 2009. ${ }^{B}$ Significant differences $(p<0.05)$ between the variable and general practitioner visit among COPD women in 2009. 'Significant differences $(p<0.05)$ between the variable and general practitioner visit among COPD men in 2014.

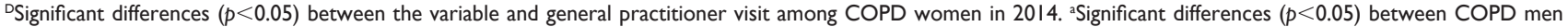
and COPD women for general practitioner visit in 2009. 'bignificant differences $(p<0.05)$ between COPD men and COPD women for general practitioner visit in 2014. cSignificant differences $(p<0.05)$ between general practitioner visit in COPD women in 2009 and general practitioner visit in COPD women in 2014.

Abbreviations: COPD, chronic obstructive pulmonary disease; EHSS, European Health Interview Surveys for Spain.

significantly more frequent in subjects with high blood pressure or any chronic comorbidity and in those with pain in the previous 4 weeks, while in women, the use was higher in younger age and in subjects with higher levels of education or monthly income, fair/poor/very poor self-rated health and pain in the last 4 weeks. In 2014, non-GP service use in men was higher in subjects with fair/poor/very poor self-rated health, pain, and no practice of physical exercise, 
Table 3 Distribution of non-general practitioner services use in COPD subjects according to demographic and socioeconomic variables, health status, and lifestyles in the EHSS, 2009 and 2014

\begin{tabular}{|c|c|c|c|c|}
\hline \multirow[t]{2}{*}{ Variables } & \multicolumn{2}{|l|}{2009} & \multicolumn{2}{|l|}{2014} \\
\hline & Men, n (\%) & Women, n (\%) & Men, n (\%) & Women, n (\%) \\
\hline \multicolumn{5}{|l|}{ Age groups ${ }^{B}$} \\
\hline $40-54$ years & $34(29.31)$ & $55(40.74)$ & $28(39.44)$ & $36(46.15)$ \\
\hline $55-69$ years $^{\mathrm{a}, \mathrm{b}}$ & $53(29.28)$ & $81(38.94)$ & $43(31.39)$ & 75 (45.73) \\
\hline 70 years or over ${ }^{\mathrm{a}, \mathrm{c}, \mathrm{d},{ }^{\circ}}$ & $65(2 I .8 I)$ & $96(30.28)$ & 99 (37.79) & $98(38.13)$ \\
\hline \multicolumn{5}{|l|}{ Educational level ${ }^{B}$} \\
\hline No formal study/primary ${ }^{a, c, d}$ & $103(24.47)$ & $153(3 \mid .88)$ & III (37) & I 34 (39.07) \\
\hline Secondary ${ }^{\mathrm{a}, \mathrm{b}}$ & $29(27.36)$ & $59(43.38)$ & $35(32.4 I)$ & $49(48.04)$ \\
\hline Higher education & $20(29.4 I)$ & $20(45.45)$ & $24(38.7 I)$ & $26(48.15)$ \\
\hline \multicolumn{5}{|l|}{ Monthly income ${ }^{B}$} \\
\hline$<850$ Euros $^{\mathrm{a}, \mathrm{c}, \mathrm{d}}$ & $32(20.13)$ & $67(29.65)$ & 61 (36.53) & $91(43.13)$ \\
\hline $850-1,400$ Euros & $45(27.44)$ & $55(33.95)$ & $30(30.6 I)$ & $39(42.86)$ \\
\hline$>1,400$ Euros $^{\mathrm{a}}$ & $58(29.15)$ & $77(4 I .62)$ & $52(37.96)$ & $44(39.29)$ \\
\hline \multicolumn{5}{|l|}{ Living with partner } \\
\hline Yes $^{\mathrm{a}, \mathrm{c}}$ & $112(27.05)$ & 117 (37.38) & $|2|(37)$ & $88(42.5 \mathrm{I})$ \\
\hline $\mathrm{No}^{\mathrm{a}, c, \mathrm{~d}}$ & $40(22.1)$ & $115(33.14)$ & $49(34.27)$ & $121(41.44)$ \\
\hline \multicolumn{5}{|l|}{ Self-rated health ${ }^{\mathrm{B}, \mathrm{C}}$} \\
\hline Very good/good ${ }^{d}$ & $36(20.69)$ & $39(25.66)$ & $36(27.07)$ & 41 (37.27) \\
\hline Fair/poor/very poor a,c & $116(27.55)$ & $193(37.99)$ & $134(39.76)$ & $168(43.19)$ \\
\hline \multicolumn{5}{|l|}{ Any chronic comorbidity $A, D$} \\
\hline $\mathrm{No}^{\mathrm{a}, \mathrm{c}}$ & $50(20.4 I)$ & $83(33.2)$ & $51(32.08)$ & $65(36.11)$ \\
\hline$Y_{e s}^{\mathrm{a}, c, \mathrm{~d}}$ & $102(29.14)$ & 149 (36.34) & $119(38.26)$ & I 44 (45.14) \\
\hline \multicolumn{5}{|l|}{ High blood pressure $\mathrm{A}^{\mathrm{A}}$} \\
\hline $\mathrm{No}^{\mathrm{a}, \mathrm{c}}$ & $70(21.74)$ & $127(37.57)$ & $83(33.2)$ & $95(38.78)$ \\
\hline$Y_{e s}^{c, d}$ & $82(30.04)$ & $105(32.6 \mathrm{I})$ & $87(39.55)$ & II (44.88) \\
\hline \multicolumn{5}{|l|}{ Mental disorder ${ }^{\mathrm{A}, \mathrm{B}, \mathrm{C}, \mathrm{D}}$} \\
\hline $\mathrm{No}^{c}$ & $118(23.23)$ & $116(28.22)$ & 125 (32.05) & $102(34.58)$ \\
\hline Yes $^{c}$ & $34(39.08)$ & $116(46.59)$ & $45(56.25)$ & $107(52.45)$ \\
\hline \multicolumn{5}{|l|}{ Pain $A, B, C$} \\
\hline $\mathrm{No}^{c, d}$ & $51(19.1)$ & $32(20.13)$ & $45(28.85)$ & $27(35.53)$ \\
\hline$Y_{e s}{ }^{a, c}$ & $101(30.79)$ & $200(39.92)$ & $125(39.81)$ & $182(43.03)$ \\
\hline \multicolumn{5}{|l|}{ Body mass index ${ }^{B}$} \\
\hline$<25 \mathrm{~kg} / \mathrm{m}^{2}$ & $38(25.33)$ & 57 (32.57) & $46(32.86)$ & $57(41.91)$ \\
\hline $25-30 \mathrm{~kg} / \mathrm{m}^{2, c, d}$ & $66(26.72)$ & $62(32.12)$ & $73(37.44)$ & 7I (43.29) \\
\hline$\geq 30 \mathrm{~kg} / \mathrm{m}^{2, a, b}$ & $42(28.38)$ & $79(43.4 I)$ & 40 (33.9) & $68(46.58)$ \\
\hline \multicolumn{5}{|l|}{ Physical exercise ${ }^{c}$} \\
\hline 0-3 days per week ${ }^{\mathrm{c}, \mathrm{d}}$ & $59(27.7)$ & $105(33.65)$ & $87(4 \mid .43)$ & $103(43.28)$ \\
\hline 4-7 days per week $\mathrm{k}^{\mathrm{a}, \mathrm{b}, \mathrm{c}}$ & $93(24.35)$ & $127(36.49)$ & $83(31.92)$ & $106(40.61)$ \\
\hline \multicolumn{5}{|l|}{ Tobacco use ${ }^{\mathrm{B}, \mathrm{C}}$} \\
\hline Current smoker & $37(22.42)$ & $44(46.8 \mathrm{I})$ & $32(26.67)$ & $37(46.25)$ \\
\hline Ex-smoker ${ }^{\mathrm{b}, \mathrm{c}, \mathrm{d}}$ & $78(28.78)$ & $26(31.71)$ & $112(39.16)$ & $41(51.25)$ \\
\hline Never smoker & $30(29.7)$ & $146(33.72)$ & $26(4 I .27)$ & $13 \mid(38.64)$ \\
\hline \multicolumn{5}{|l|}{ Alcohol consumption ${ }^{c}$} \\
\hline $\mathrm{No}^{\mathrm{a}, c, \mathrm{~d}}$ & $77(25.67)$ & $189(34.3)$ & $93(43.46)$ & $166(44.03)$ \\
\hline Yes $^{\mathrm{a}}$ & $75(25.42)$ & $43(39.45)$ & $77(30.08)$ & $43(35.25)$ \\
\hline Total $^{\mathrm{a}, \mathrm{c}, \mathrm{d}}$ & $152(25.55)$ & $232(35.15)$ & $170(36.17)$ & $209(41.88)$ \\
\hline
\end{tabular}

Notes: ${ }^{A}$ Significant differences $(p<0.05)$ between the variable and non-general practitioner services use among COPD men in 2009. ${ }^{B}$ Significant differences $(p<0.05)$ between the variable and non-general practitioner services use among COPD women in 2009. CSignificant differences $(p<0.05)$ between the variable and non-general practitioner services use among COPD men in 2014. DSignificant differences $(p<0.05)$ between the variable and non-general practitioner services use among COPD women in 2014. ${ }^{a}$ Significant differences $(p<0.05)$ between COPD men and COPD women for non-general practitioner services use in 2009. ${ }^{b}$ Significant differences $(p<0.05)$ between COPD men and COPD women for non-general practitioner services use in 2014. 'Significant differences $(p<0.05)$ between non-general practitioner services use in COPD men in 2009 and non-general practitioner services use in COPD men in 2014. dSignificant differences $(p<0.05)$ between non-general practitioner services use in COPD women in 2009 and non-general practitioner services use in COPD women in 2014.

Abbreviations: COPD, chronic obstructive pulmonary disease; EHSS, European Health Interview Surveys for Spain.

while it was significantly more frequent in those with any chronic comorbidity. When comparing the results between men and women with COPD in 2009, we found that, overall, women significantly used more non-GP services than men
(35.15\% vs $25.55 \%)$. On the other hand, we observed that the prevalence of non-GP service use was significantly increased in men and women with COPD between 2009 and 2014 ( $25.55 \%$ vs $36.17 \%$ and $35.15 \%$ vs $42.88 \%$, respectively). 
Table 4 shows the distribution of home care service use in the last year among COPD subjects. In both surveys and for both sexes, we found that subjects with older age, lower educational levels, fair/poor/very poor self-rated health, any chronic comorbidity, pain and no practice physical activity in their free time had significantly higher frequency of use. When comparing the overall results between men and women with COPD in both surveys, we found that women

Table 4 Distribution of home care services use in COPD subjects according to demographic and socioeconomic variables, health status and lifestyles in the EHSS, 2009 and 2014

\begin{tabular}{|c|c|c|c|c|}
\hline \multirow[t]{2}{*}{ Variables } & \multicolumn{2}{|l|}{2009} & \multicolumn{2}{|l|}{2014} \\
\hline & Men, n (\%) & Women, n (\%) & Men, n (\%) & Women, n (\%) \\
\hline \multicolumn{5}{|l|}{ Age groups ${ }^{A, B, C, D}$} \\
\hline $40-54$ years $^{\mathrm{a}}$ & $2(1.72)$ & $10(7.4 \mathrm{I})$ & $4(5.63)$ & $3(3.85)$ \\
\hline $55-69$ years $^{d}$ & $8(4.42)$ & $10(4.81)$ & II (8.03) & $17(10.37)$ \\
\hline 70 years or over ${ }^{\mathrm{a}, \mathrm{b}}$ & $62(20.81)$ & $110(34.7)$ & $56(21.37)$ & $88(34.24)$ \\
\hline \multicolumn{5}{|l|}{ Educational level $\left.\right|^{A, B, C, D}$} \\
\hline No formal study/primary & 61 (14.49) & $114(23.75)$ & $57(19)$ & $97(28.28)$ \\
\hline Secondary & $8(7.55)$ & II (8.09) & $8(7.4 I)$ & $10(9.8)$ \\
\hline Higher education & $3(4.4 I)$ & 5 (II.36) & $6(9.68)$ & I (I.85) \\
\hline \multicolumn{5}{|l|}{ Monthly income $e^{A, B, D}$} \\
\hline$<850$ Euros & $24(15.09)$ & $63(27.88)$ & $34(20.36)$ & $69(32.7)$ \\
\hline $850-1,400$ Euros & $29(17.68)$ & $29(17.9)$ & $14(\mid 4.29)$ & $16(17.58)$ \\
\hline$>1,400$ Euros $^{\mathrm{a}}$ & $14(7.04)$ & $26(14.05)$ & $17(12.4 I)$ & $9(8.04)$ \\
\hline \multicolumn{5}{|l|}{ Living with partner ${ }^{A, B, D}$} \\
\hline Yes $^{c}$ & $4 \mid(9.9)$ & $4 I(13.1)$ & $50(I 5.29)$ & $25(12.08)$ \\
\hline $\mathrm{No}^{\mathrm{a}, \mathrm{b}}$ & $31(17.13)$ & $89(25.65)$ & $21(14.69)$ & $83(28.42)$ \\
\hline \multicolumn{5}{|l|}{ Self-rated health ${ }^{A, B, C, D}$} \\
\hline Very good/good ${ }^{a}$ & $4(2.3)$ & II (7.24) & $6(4.5 I)$ & $8(7.27)$ \\
\hline Fair/poor/very poor ${ }^{\mathrm{a}, \mathrm{b}}$ & $68(16.15)$ & $119(23.43)$ & $65(19.29)$ & $100(25.7 \mathrm{I})$ \\
\hline \multicolumn{5}{|l|}{ Any chronic comorbidity ${ }^{A, B, C, D}$} \\
\hline $\mathrm{No}^{\mathrm{a}}$ & $12(4.9)$ & $30(12)$ & $15(9.43)$ & $27(15)$ \\
\hline$Y_{e s}^{\mathrm{a}, \mathrm{b}}$ & $60(17.14)$ & $100(24.39)$ & $56(|8.0|)$ & $81(25.39)$ \\
\hline \multicolumn{5}{|l|}{ High blood pressure ${ }^{A, B, C}$} \\
\hline $\mathrm{No}^{c}$ & $30(9.32)$ & 38 (II.24) & $39(15.6)$ & $36(14.69)$ \\
\hline$Y_{e s}^{\mathrm{a}, \mathrm{b}}$ & $42(15.38)$ & $92(28.57)$ & $32(14.55)$ & $72(28.35)$ \\
\hline \multicolumn{5}{|l|}{ Mental disorder ${ }^{A, B, C}$} \\
\hline $\mathrm{No}^{\mathrm{a}}$ & $54(10.63)$ & $70(17.03)$ & 53 (I3.59) & $56(18.98)$ \\
\hline Yes & $18(20.69)$ & $60(24.1)$ & $18(22.5)$ & $52(25.49)$ \\
\hline \multicolumn{5}{|l|}{ Pain $A, B, C, D$} \\
\hline No & $18(6.74)$ & $19(11.95)$ & $15(9.62)$ & $6(7.89)$ \\
\hline$Y_{e s}^{a, b}$ & $54(16.46)$ & $111(22.16)$ & $56(17.83)$ & $102(24.11)$ \\
\hline \multicolumn{5}{|l|}{ Body mass index } \\
\hline$<25 \mathrm{~kg} / \mathrm{m}^{2}$ & $23(15.33)$ & $27(\mid 5.43)$ & $26(18.57)$ & $26(19.12)$ \\
\hline $25-30 \mathrm{~kg} / \mathrm{m}^{2, a}$ & $23(9.31)$ & $30(15.54)$ & $22(I 1.28)$ & $26(15.85)$ \\
\hline$\geq 30 \mathrm{~kg} / \mathrm{m}^{2, \mathrm{a}, \mathrm{b}}$ & $13(8.78)$ & $4 \mathrm{I}(22.53)$ & $15(12.71)$ & $39(26.71)$ \\
\hline \multicolumn{5}{|l|}{ Physical exercise ${ }^{A, B, C, D}$} \\
\hline 0-3 days per week & $50(23.47)$ & $90(28.85)$ & $52(24.76)$ & $76(31.93)$ \\
\hline 4-7 days per week ${ }^{\mathrm{a}}$ & $22(5.76)$ & 40 (II.49) & $19(7.31)$ & $32(12.26)$ \\
\hline \multicolumn{5}{|l|}{ Tobacco use $\mathrm{e}^{\mathrm{A}, \mathrm{B}, \mathrm{C}, \mathrm{D}}$} \\
\hline Current smoker & $6(3.64)$ & $6(6.38)$ & $7(5.83)$ & $8(10)$ \\
\hline Ex-smoker & $40(14.76)$ & $12(14.63)$ & $56(19.58)$ & $14(17.5)$ \\
\hline Never smoker ${ }^{\mathrm{a}, \mathrm{b}}$ & $8(7.92)$ & $91(21.02)$ & $8(12.7)$ & $86(25.37)$ \\
\hline \multicolumn{5}{|l|}{ Alcohol consumption ${ }^{\mathrm{A}, \mathrm{B}, \mathrm{C}, \mathrm{D}}$} \\
\hline No & $57(19)$ & $122(22.14)$ & $45(21.03)$ & $92(24.4)$ \\
\hline $\mathrm{Yes}^{\mathrm{c}}$ & $15(5.08)$ & $8(7.34)$ & $26(10.16)$ & $16(13.11)$ \\
\hline Total $\left.\right|^{\mathrm{a}, \mathrm{b}}$ & $72(12.1)$ & $130(19.7)$ & $71(15.11)$ & $108(21.64)$ \\
\hline
\end{tabular}

Notes: ${ }^{A}$ Significant differences $(p<0.05)$ between the variable and home care services use among COPD men in 2009. ${ }^{B}$ Significant differences $(p<0.05)$ between the variable and home care services use among COPD women in 2009. ${ }^{C}$ Significant differences $(p<0.05)$ between the variable and home care services use among COPD men in 2014. DSignificant differences $(p<0.05)$ between the variable and home care services use among COPD women in 2014. asignificant differences $(p<0.05)$ between COPD men and COPD women for home care services use in 2009. bignificant differences $(p<0.05)$ between COPD men and COPD women for home care services use in 2014. 'Significant differences $(p<0.05)$ between home care services use in COPD men in 2009 and home care services use in COPD men in 2014. ${ }^{d}$ Significant differences $(p<0.05)$ between home care services use in COPD women in 2009 and home care services use in COPD women in 2014.

Abbreviations: COPD, chronic obstructive pulmonary disease; EHSS, European Health Interview Surveys for Spain. 
significantly used more home care services than men $(19.7 \%$ vs $12.1 \%$ in 2009 and $21.64 \%$ vs $15.11 \%$ in 2014$)$. We observed that the prevalence of home care service use remained unchanged over the study period.

Table 5 shows the results of the multivariable logistic regression models conducted to identify those variables that were significantly associated with a higher use of health and home care services among COPD subjects included in the two EHSS together. The presence of any chronic comorbidity was associated with a higher use of all the services analyzed (OR 1.79, 95\% CI 1.41-2.64 for hospitalizations; OR 1.32, 95\% CI 1.06-1.65 for GP visits; OR 1.29, 95\% CI 1.04-1.59 for non-GP service use; and OR 1.74, 95\% CI 1.22-2.46 for home care service use). High blood pressure was also associated with a higher probability of GP visits (OR 1.56, 95\% CI 1.25-1.93). Worse self-rated health was associated

Table 5 Multivariable model to assess variables associated to health and home care services use among Spanish COPD subjects included in the EHSS 2009 and 2014

\begin{tabular}{|c|c|c|c|c|}
\hline Variables & $\begin{array}{l}\text { Hospitalization, } \\
\text { OR }(95 \% \mathrm{Cl})\end{array}$ & $\begin{array}{l}\text { General practitioner } \\
\text { visit, OR }(95 \% \mathrm{Cl})\end{array}$ & $\begin{array}{l}\text { Non-general practitioner } \\
\text { services use, OR }(95 \% \mathrm{Cl})\end{array}$ & $\begin{array}{l}\text { Home care services } \\
\text { use, OR }(95 \% \mathrm{Cl})\end{array}$ \\
\hline \multicolumn{5}{|l|}{ Gender } \\
\hline Men & I & I & I & I \\
\hline Women & $0.72(0.58-0.89)$ & $0.96(0.76-1.21)$ & I.II (0.9I-I.37) & $\mathrm{I} .14(0.82-1.59)$ \\
\hline \multicolumn{5}{|l|}{ Age groups } \\
\hline $40-54$ years & I & I & I & I \\
\hline $55-69$ years & $1.30(0.91-1.87)$ & $1.47(1.08-1.99)$ & $0.74(0.55-0.98)$ & $1.32(0.67-2.58)$ \\
\hline 70 years or over & $2.02(\mathrm{I} .45-2.83)$ & $1.94(1.44-2.62)$ & $0.67(0.50-0.88)$ & $5.66(3.08-10.39)$ \\
\hline \multicolumn{5}{|l|}{ Monthly income } \\
\hline$<850$ Euros & & I & I & 1 \\
\hline $850-1,400$ Euros & & $1.20(0.92-1.57)$ & $1.12(0.88-1.44)$ & $0.87(0.61-1.24)$ \\
\hline$>1,400$ Euros & & $0.77(0.59-0.98)$ & $1.35(\mid .06-1.7 I)$ & $0.64(0.44-0.93)$ \\
\hline \multicolumn{5}{|l|}{ Living with partner } \\
\hline Yes & & 1 & & 1 \\
\hline No & & $0.73(0.58-0.92)$ & & $1.36(1.02-1.86)$ \\
\hline \multicolumn{5}{|l|}{ Self-rated health } \\
\hline Very good/good & I & 1 & & I \\
\hline Fair/poor/very poor & $2.68(1.96-3.67)$ & $1.40(1.08-1.82)$ & & $2.55(1.52-4.28)$ \\
\hline \multicolumn{5}{|c|}{ Any chronic comorbidity } \\
\hline No & I & I & I & I \\
\hline Yes & $\mathrm{I} .79(\mathrm{I} .4 \mathrm{I}-2.64)$ & $1.32(1.06-1.65)$ & $1.29(1.04-1.59)$ & $1.74(1.22-2.46)$ \\
\hline \multicolumn{5}{|l|}{ Mental disorder } \\
\hline No & I & I & I & I \\
\hline Yes & $1.25(0.98-1.58)$ & $1.32(1.02-1.70)$ & $1.93(I .54-2.4 I)$ & $1.75(1.27-2.42)$ \\
\hline \multicolumn{5}{|l|}{ High blood pressure } \\
\hline No & & I & & \\
\hline Yes & & $1.56(1.25-1.93)$ & & \\
\hline \multicolumn{5}{|l|}{ Pain } \\
\hline No & & I & I & \\
\hline Yes & & I.87 (I.47-2.38) & $1.73(1.36-2.20)$ & \\
\hline \multicolumn{5}{|l|}{ Body mass index } \\
\hline$<25 \mathrm{~kg} / \mathrm{m}^{2}$ & & I & & I \\
\hline $25-30 \mathrm{~kg} / \mathrm{m}^{2}$ & & $0.97(0.76-1.25)$ & & $0.63(0.44-0.89)$ \\
\hline$\geq 30 \mathrm{~kg} / \mathrm{m}^{2}$ & & $0.72(0.55-0.96)$ & & $0.66(0.46-0.96)$ \\
\hline \multicolumn{5}{|l|}{ Physical exercise } \\
\hline 0-3 days per week & I & & & I \\
\hline 4-7 days per week & $0.72(0.59-0.89)$ & & & $0.37(0.27-0.50)$ \\
\hline \multicolumn{5}{|l|}{ Alcohol consumption } \\
\hline No & & 1 & & 1 \\
\hline Yes & & $0.68(0.54-0.86)$ & & $0.53(0.36-0.77)$ \\
\hline \multicolumn{5}{|l|}{ EHSS } \\
\hline 2009 & I & & & \\
\hline 2014 & I.0I (0.96-1.04) & $0.98(0.94-1.02)$ & 1.41 (1.16-I.72) & I.0I (0.82-I.59) \\
\hline
\end{tabular}

Abbreviations: COPD, chronic obstructive pulmonary disease; EHSS, European Health Interview Surveys for Spain. 
a higher probability of hospitalizations (OR 2.68, 95\% CI 1.96-3.67), GP visits (OR 1.40, 95\% CI 1.08-1.82) and home care service use (OR 2.55, 95\% CI 1.52-4.28). The highest OR was found in those elderly COPD subjects (70 years or over) who had a 2.02 greater probability of hospitalization, 1.94 greater probability of a GP visit and a 5.66 greater probability of using home care services than younger patients. The presence of pain increased the probability of visiting the GP as occurred with the presence of mental disorders.

On the other hand, female sex decreased the probability of hospitalization (OR 0.72 , 95\% CI 0.58-0.89). COPD subjects who lived with a parent had a lower probability of a GP visit (OR 0.73, 95\% CI 0.58-0.92), and those who practiced more physical exercise had a lower probability of hospitalization (OR 0.72, 95\% CI 0.59-0.89). Further, higher monthly income was associated with a lower probability of a GP visit or home care service use, as occurred with the higher body mass index and alcohol consumption. The time trend analysis showed that non-GP service use increased from 2009 to 2014. However, we did not find significant variations for hospitalization, GP visits and home care service use.

Tables S2 and S3 show the variables that were significantly associated with a higher use of health and home care services among COPD subjects in the EHSS 2009 (Table S2) and in the EHSS 2014 (Table S3) after multivariable analysis. The variables found in each of the two EHSSs separately were very similar to those described in the model conducted with both surveys together.

The results of the sensitivity analysis are shown in Table S4. The model conducted, excluding the variable "monthly income", yielded the same time trend results as the model with this variable included; that is, a significant increase in the use of non-GP services with no significant changes for the other three study variables.

\section{Discussion}

In this study, using cross-sectional data, we found that the utilization of non-GP services that included nursing, rehabilitation, and psychological services, increased significantly among the Spanish COPD population from 2009 to 2014. Variables associated with the use of these services were female sex, younger age, higher monthly income, pain sufferer or any chronic comorbidity and the presence of mental disorders. However, we did not find variations in other healthcare service use, such as hospitalizations, GP visits, and home care services over time. A possible explanation for these findings is the impact of the economic crisis on the health of the population. ${ }^{17,18}$ Gili et $\mathrm{al}^{19}$ indicated that the recession has significantly increased the frequency of mental health disorders among primary care attendees in Spain, which could explain the higher use of psychological services among COPD patients. On the other hand, Regidor et $\mathrm{al}^{20}$ also attempted to identify any changes in health indicators during the financial crisis and concluded that Spanish health actually improved at a rate equal to or higher than what had occurred in the years prior to recession. In spite of this, in our study, we observed an increase in the consumption of tobacco and alcohol during the economic crisis. Other authors also suggested that when financial pressures increase, the risks of heavy drinking and smoking are also likely to increase. ${ }^{21}$

We also documented that female sex was associated with a lower probability of hospitalization. Other authors have found similar findings. ${ }^{22,23}$ These results may suggest a difference between genders in the management of COPD, as has been previously described..$^{24}$ By contrast, variables associated with a higher risk of hospitalization in our study included older age, suffering of any chronic comorbidity and the presence of mental disorders. Singh and $\mathrm{Yu}^{25}$ also found that older age and the presence of comorbidities were associated with hospital admission in COPD patients, together with others factors such as higher household income and metropolitan residence. Although previous studies have focused on pulmonary function status and COPD medication as predictors of health resource utilization, they did not examine sociodemographic factors and comorbidities, as we have done. ${ }^{26,27}$

The health status of patients with COPD is worse than in the general population. ${ }^{7}$ There is evidence that selfperceived health is a valid measure predicting unfavorable health outcomes and healthcare utilization and a goal for effective self-management. ${ }^{28,29}$ Our findings confirmed that worse self-reported health was a predictor of higher use of hospitalizations, GP visits and home care service use among COPD sufferers. Nevertheless, self-rated health did not change significantly from 2009 to 2014 . Other studies have also found that the financial crisis has not altered the likelihood of reporting poor self-perceived health. ${ }^{30}$

The association of higher monthly income with a higher risk of non-GP service use is interesting and extends a similar finding from other authors, who have suggested that monthly income reflects education levels or health literature levels, both of which might affect the healthcare resource use. ${ }^{25}$ We believe, like others, that the changes in the perception of health that have occurred in our society, with an increase in expectations and changes in attitudes in relation to health, have led to a greater use of nurse care, rehabilitation and psychological services. ${ }^{31,32}$ 
Comorbidities occur more commonly among people with COPD than in the general population and are associated with reduced quality of life and increased health resource use. ${ }^{33,34}$ Our study is consistent with other reports documenting the burden of comorbid disorders among COPD patients. ${ }^{35}$ The presence of any chronic comorbidity was a strong predictor of health service utilization, including hospitalizations, GP visits, non-GP service use and home care service utilization. Mental disorder was also a predictor of higher use of GP visits and home care services. Therefore, the recognition of mental health problems associated with COPD should be an important part of the management plan of this disease, as a potentially modifiable target to reduce healthcare resource utilization. ${ }^{36}$ On the other hand, pain is emerging as a clinical complication in COPD. It has negative clinical associations with symptoms and quality of life measures. ${ }^{37}$ However, the impact of this comorbidity on the use of health services is poorly understood. Our study demonstrated that the presence of pain was associated with a higher probability of GP visits and non-GP service utilization.

Physical activity is a modifiable behavior that is associated with COPD outcomes. The Global Strategy for the Diagnosis, Management, and Prevention of Chronic Obstructive Lung Disease 2017 Report guidelines recommend regular physical activity for patients with stable COPD. ${ }^{38}$ Higher levels of physical activity are associated with decreased risk of hospitalizations and mortality, independent of airflow obstruction. ${ }^{39}$ In the present study, physical activity was associated not only with lower use of hospitals but also with home care services among COPD patients. This finding is consistent with that found by Perkins and Clark, who evaluated the association between self-reported exercise and health service use in order adults with multiple comorbidities. ${ }^{40}$

The strengths of our study include large sample sizes, a randomly selected population, the employment of standardized surveys, and training of the data collectors. However, several limitations should be noted. First, our definition of COPD was based on self-reported physician diagnoses of the disease, and the validity of the self-reported conditions included in the EHSS have not been evaluated. However, the approach used in this study to identify COPD patients has been widely used in large international surveys and has proven to be reasonably reliable. ${ }^{41,42}$ Second, we have no information about the severity of the airflow obstruction. Third, data collections in the EHSS did not include detailed assessment of COPD medications, which would have provided additional insights. Fourth, information on the validity of the questions regarding the use of health and home care services has not been evaluated. In any case, we think that the memory bias or the socially conditioned answers that could affect the validity of these questions is similar in both surveys and, therefore, would not affect the main conclusion regarding the time trend analysis. Finally, the response rates for the EHSS 2009 and 2014 were approximately $65 \%$ and $61 \%$, respectively, so the existence of a selection bias must be considered. ${ }^{11,12}$

\section{Conclusion}

We found an increase in the use of non-GP service use (nursing, rehabilitation, and psychological) but not in other health and home care services. The only differences in hospitalizations were observed according to sex, with lower use among women. Therefore, the effect of the economic crisis, if any, seems to have been of small magnitude. More research is necessary to assess the effect of health policy responses to the crisis after 2014.

\section{Acknowledgments}

This study is part of the research funded by the FIS (Fondo de Investigaciones Sanitarias-Health Research Fund, grant number PI16/00564, Instituto de Salud Carlos III), cofinanced by the European Union through the Fondo Europeo de Desarrollo Regional (FEDER, "Una manera de hacer Europa") and by the Grupo de Excelencia Investigadora URJC-Banco Santander No30VCPIGI03: Investigación traslacional en el proceso de salud - enfermedad (ITPSE).

\section{Disclosure}

The authors report no conflicts of interest in this work.

\section{References}

1. Soriano JB, Rodríguez-Roisin R. Chronic obstructive pulmonary disease overview: epidemiology, risk factors, and clinical presentation. Proc Am Thorac Soc. 2011;8(4):363-367.

2. Buist AS, McBurnie MA, Vollmer WM, Gillespie S, et al. International variation in the prevalence of COPD (the BOLD Study): a populationbased prevalence study. Lancet. 2007;370(9589):741-750.

3. Yeo J, Karimova G, Bansal S. Co-morbidity in older patients with COPDits impact on health service utilisation and quality of life, a community study. Age Ageing. 2006;35(1):33-37.

4. Ding B, DiBonaventura M, Karlsson N, Bergström G, Holmgren U. A cross-sectional assessment of the burden of COPD symptoms in the US and Europe using the National Health and Wellness Survey. Int $J$ Chron Obstruct Pulmon Dis. 2017;12:529-539.

5. Luk EK, Hutchinson AF, Tacey M, Irving L, Khan F. COPD: health care utilisation patterns with different disease management interventions. Lung. 2017;195(4):455-461.

6. García-Polo C, Alcázar-Navarrete B, Ruiz-Iturriaga LA, et al. Factors associated with high healthcare resource utilisation among COPD patients. Respir Med. 2012;106(12):1734-1742.

7. de Miguel Díez J, Jiménez García R, Hernández Barrera V, et al. Trends in self-rated health status and health services use in COPD patients (2006-2012). A Spanish population-based survey. Lung. 2015;193(1): 53-62. 
8. van der Molen T. Co-morbidities of COPD in primary care: frequency, relation to COPD, and treatment consequences. Prim Care Respir J. 2010;19(4):326-334.

9. Wijnhoven HA, Kriegsman DM, Hesselink AE, de Haan M, Schellevis FG. The influence of co-morbidity on health-related quality of life in asthma and COPD patients. Respir Med. 2003;97(5):468-475.

10. Gené-Badia J, Gallo P, Hernández-Quevedo C, García-Armesto S. Spanish health care cuts: penny wise and pound foolish? Health Policy. 2012;106(1):23-28.

11. Instituto Nacional de Estadistica. Encuesta Europea de Salud en España [European Health Interview Survey for Spain]; 2009. Available from: http://www.ine.es/metodologia/t15/t153042009.pdf. Accessed July 20, 2017. Spanish.

12. Instituto Nacional de Estadistica. Encuesta Europea de la Salud en España [European Health Interview Survey for Spain]; 2014. Available from: http://www.ine.es/metodologia/t15/t153042014.pdf. Accessed July 20, 2017. Spanish.

13. European Commission. Eurostat. The European Health Interview Survey. Available from: http://ec.europa.eu/eurostat/web/microdata/ european-health-interview-survey. Accessed February 23, 2017.

14. Palacios-Ceña D, Hernández-Barrera V, Jiménez-García R, ValleMartín B, Fernández-de-las-Peñas C, Carrasco-Garrido P. Has the prevalence of health care services use increased over the last decade (2001-2009) in elderly people? A Spanish population-based survey. Maturitas. 2013;76(4):326-333.

15. Ministerio de Sanidad y Política Social Orden SAS/3470/2009, de 16 de diciembre, por la que se publican las directrices sobre estudios posautorización de tipo observacional para medicamentos de uso humano. BOE 2009;310:109761-109775 [Ministry of Health and Social Policy Order SAS/3470/2009, of December 16, which publishes guidelines on observational post-authorization studies for medicines for human use]. Available from: https://www.boe.es/boe/dias/2009/12/25/pdfs/ BOE-A-2009-20817.pdf. Accessed November 23, 2017. Spanish.

16. Instituto Nacional de Estadistica. Encuesta europea de salud en España [European Health Interview Surveys for Spain]. Available from: http://www.ine.es/dyngs/INEbase/es/operacion.htm?c=Estadistica_C\& cid $=1254736176784 \&$ menu $=$ resultados $\&$ secc $=1254736195298 \& \mathrm{idp}=$ 1254735573175. Accessed November 23, 2017. Spanish.

17. Houston M, Day M, de Lago M, Zarocostas J. Health services across Europe face cuts as debt crisis begins to bite. BMJ. 2011;343:d5266.

18. Márquez-Calderón S, Villegas-Portero R, Gosalbes Soler V, MartínezPecino F. Promoción de la salud y prevención en tiempos de crisis: el rol del sector sanitario. Informe SESPAS 2014 [Health promotion and prevention in the economic crisis: the role of the health sector. SESPAS report 2014]. Gac Sanit. 2014;28 Suppl 1:116-123. Spanish.

19. Gili M, Roca M, Basu S, McKee M, Stuckler D. The mental health risks of economic crisis in Spain: evidence from primary care centres, 2006 and 2010. Eur J Public Health. 2013;23(1):103-108.

20. Regidor E, Barrio G, Bravo MJ, de la Fuente L. Has health in Spain been declining since the economic crisis? J Epidemiol Community Health. 2014;68(3):280-282.

21. Shaw BA, Agahi N, Krause N. Are changes in financial strain associated with changes in alcohol use and smoking among older adults? J Stud Alcohol Drugs. 2011;72(6):917-925.

22. Milne RJ, Beasley R. Hospital admissions for chronic obstructive pulmonary disease in New Zealand. NZ Med J. 2015;128(1408):23-35.

23. Atun R, Gurol-Urganci I, Hone T, et al. Shifting chronic disease management from hospitals to primary care in Estonian health system: analysis of national panel data. J Glob Health. 2016;6(2):020701.

24. Delgado A, Saletti-Cuesta L, López-Fernández LA, Gil-Garrido N, Luna Del Castillo Jde D. Gender inequalities in COPD decision-making in primary care. Respir Med. 2016;114:91-96.

25. Singh JA, Yu S. Utilization due to chronic obstructive pulmonary disease and its predictors: a study using the U.S. National Emergency Department Sample (NEDS). Respir Res. 2016;17:1.
26. Bahadori K, FitzGerald JM. Risk factors of hospitalization and readmission of patients with COPD exacerbation - systematic review. Int J Chron Obstruct Pulmon Dis. 2007;2(3):241-251.

27. Blais L, Forget A, Ramachandran S. Relative effectiveness of budesonide/formoterol and fluticasone propionate/salmeterol in a 1-year, population-based, matched cohort study of patients with chronic obstructive pulmonary disease (COPD): effect on COPD-related exacerbations, emergency department visits and hospitalizations, medication utilization, and treatment adherence. Clin Ther. 2010;32(7): $1320-1328$

28. Jylhä M. What is self-rated health and why does it predict mortality? Towards a unified conceptual model. Soc Sci Med. 2009;69(3): 307-316.

29. Benzo RP, Abascal-Bolado B, Dulohery MM. Self-management and quality of life in chronic obstructive pulmonary disease (COPD): the mediating effects of positive affect. Patient Educ Couns. 2016;99(4): 617-623.

30. Arroyo E, Renart G, Saez M. How the economic recession has changed the likelihood of reporting poor self-rated health in Spain. Int J Equity Health. 2015;14:149.

31. Ros JM, Recio AO, Gil SP, Arambarri MJ, Eizaguirre JM, Carretero MJ; Miembros del Grupo de Investigación de la Comarca Oeste de Gipuzkoa (CGO). Consulta de atención primaria: ¿todo es del médico? [Primary care consultations: are they all by the doctor?] Aten Primaria. 2011;43(10):516-522. Spanish.

32. van Dijk CE, Verheij RA, Hansen J, van der Velden L, Nijpels G, Groenewegen PP, de Bakker DH. Primary care nurses: effects on secondary care referrals for diabetes. BMC Health Serv Res. 2010;10:230.

33. Putcha N, Puhan MA, Hansel NN, Drummond MB, Boyd CM. Impact of co-morbidities on self-rated health in self-reported COPD: an analysis of NHANES 2001-2008. COPD. 2013;10(3):324-332.

34. Gershon AS, Mecredy GC, Guan J, Victor JC, Goldstein R, To T. Quantifying comorbidity in individuals with COPD: a population study. Eur Respir J. 2015;45(1):51-59.

35. Westney G, Foreman MG, Xu J, Henriques King M, Flenaugh E, Rust G. Impact of comorbidities among Medicaid enrollees with chronic obstructive pulmonary disease, United States, 2009. Prev Chronic Dis. 2017;14:E31.

36. Yohannes AM, Leroi I. Treat the brain to improve the lungs?: mental illness as a risk factor for readmission in COPD. Chest. 2016;149(4): $887-888$.

37. Lee AL, Harrison SL, Goldstein RS, Brooks D. Pain and its clinical associations in individuals with COPD: a systematic review. Chest. 2015; 147(5):1246-1258.

38. Vogelmeier CF, Criner GJ, Martinez FJ, et al. Global Strategy for the Diagnosis, Management, and Prevention of Chronic Obstructive Lung Disease 2017 Report. GOLD Executive Summary. Am J Respir Crit Care Med. 2017;195(5):557-582.

39. Garcia-Aymerich J, Lange P, Benet M, Schnohr P, Antó JM. Regular physical activity reduces hospital admission and mortality in chronic obstructive pulmonary disease: a population based cohort study. Thorax. 2006;61(9):772-778.

40. Perkins AJ, Clark DO. Assessing the association of walking with health services use and costs among socioeconomically disadvantaged older adults. Prev Med. 2001;32(6):492-501.

41. de Marco R, Pesce G, Marcon A, et al. The coexistence of asthma and chronic obstructive pulmonary disease (COPD): prevalence and risk factors in young, middle-aged and elderly people from the general population. PLoS One. 2013;8(5):e62985.

42. Schnell K, Weiss CO, Lee T, Krishnan JA, Leff B, Wolff JL, Boyd C. The prevalence of clinically-relevant comorbid conditions in patients with physician-diagnosed COPD: a cross-sectional study using data from NHANES 1999-2008. BMC Pulm Med. 2012;9:12-26. 


\section{Supplementary materials}

Table SI Distribution of the study populations (COPD sufferers) according to demographic and socioeconomic variables, health status, lifestyles, and health care resources use in the EHSS, 2009 and 2014

\begin{tabular}{|c|c|c|c|}
\hline Variables & EHSS 2009 & EHSS 2014 & $p$-value \\
\hline Gender & & & 0.609 \\
\hline Men & $595(47.4 I)$ & $470(48.5)$ & \\
\hline Women & $660(52.59)$ & $499(51.5)$ & \\
\hline Age groups & & & 0.013 \\
\hline $40-54$ years & $25 I(20)$ & $149(15.38)$ & \\
\hline $55-69$ years & $389(31)$ & $301(31.06)$ & \\
\hline 70 years or over & $615(49)$ & $519(53.56)$ & \\
\hline Educational level & & & 0.012 \\
\hline No studies/primary & 901 (71.79) & $643(66.36)$ & \\
\hline Secondary & $242(19.28)$ & $210(21.67)$ & \\
\hline High education & $112(8.92)$ & $116(11.97)$ & \\
\hline Monthly income & & & 0.000 \\
\hline$<850$ Euros & $385(35.16)$ & $378(46.32)$ & \\
\hline $850-1,400$ Euros & $326(29.77)$ & $189(23.16)$ & \\
\hline$>1,400$ Euros & $384(35.07)$ & $249(30.5 I)$ & \\
\hline Living with partner & & & 0.183 \\
\hline Yes & $727(57.93)$ & $534(55.11)$ & \\
\hline No & $528(42.07)$ & 435 (44.89) & \\
\hline Self-rated health & & & 0.630 \\
\hline Very good/good & $326(25.98)$ & $243(25.08)$ & \\
\hline Fair/poor/very poor & $929(74.02)$ & $726(74.92)$ & \\
\hline Any chronic comorbidity & & & 0.031 \\
\hline No & $495(39.44)$ & $339(34.98)$ & \\
\hline Yes & $760(60.56)$ & $630(65.02)$ & \\
\hline High blood pressure & & & 0.481 \\
\hline No & $660(52.59)$ & $495(51.08)$ & \\
\hline Yes & $595(47.4 I)$ & $474(48.92)$ & \\
\hline Mental disorder ${ }^{b}$ & & & 0.186 \\
\hline No & $919(73.23)$ & $685(70.69)$ & \\
\hline Yes & $336(26.77)$ & $284(29.3 I)$ & \\
\hline Pain & & & 0.000 \\
\hline No & $426(33.94)$ & $232(23.94)$ & \\
\hline Yes & $829(66.06)$ & $737(76.06)$ & \\
\hline Body mass index & & & 0.871 \\
\hline$<25 \mathrm{~kg} / \mathrm{m}^{2}$ & $325(29.68)$ & $276(30.7)$ & \\
\hline $25-30 \mathrm{~kg} / \mathrm{m}^{2}$ & $440(40.18)$ & $359(39.93)$ & \\
\hline$\geq 30 \mathrm{~kg} / \mathrm{m}^{2}$ & $330(30.14)$ & $264(29.37)$ & \\
\hline Physical exercise ${ }^{c}$ & & & 0.038 \\
\hline 0-3 days per week & $525(41.83)$ & $448(46.23)$ & \\
\hline 4-7 days per week & $730(58.17)$ & $521(53.77)$ & \\
\hline Tobacco use & & & 0.003 \\
\hline Current smoker & $259(22.6)$ & $200(20.66)$ & \\
\hline Ex-smoker & $353(30.8)$ & $366(37.81)$ & \\
\hline Never smoker & $534(46.6)$ & $402(41.53)$ & \\
\hline Alcohol consumption $^{d}$ & & & 0.001 \\
\hline No & $85 I(67.8 I)$ & $591(60.99)$ & \\
\hline Yes & $404(32.19)$ & $378(39.01)$ & \\
\hline Hospitalization & & & 0.317 \\
\hline No & $967(77.05)$ & $729(75.23)$ & \\
\hline Yes & $288(22.95)$ & $240(24.77)$ & \\
\hline General practitioner visit & & & 0.888 \\
\hline No & $548(43.67)$ & $426(43.96)$ & \\
\hline Yes & $707(56.33)$ & $543(56.04)$ & \\
\hline
\end{tabular}


Table SI (Continued)

\begin{tabular}{lll}
\hline Variables & EHSS 2009 & EHSS 20I4 \\
\hline Home care services use & & 0.140 \\
No & $1,053(83.9)$ & $790(8 I .53)$ \\
Yes & $202(16.1)$ & $179(18.47)$ \\
Non-general practitioner service use & & $590(60.89)$ \\
No & $871(69.4)$ & $379(39.1 I)$ \\
Yes & $384(30.6)$ & 0.000 \\
\hline
\end{tabular}

Notes: Non-general practitioner services use included utilization of nurse care services/rehabilitative care services/psychological care services. ${ }^{a}$ Any chronic comorbidity included asthma, coronary disease, myocardial infarction, angina, cerebral infarction, cerebral hemorrhage, cerebral embolism and cancer. ${ }^{b}$ Mental disorder included anxiety and depression. 'Physical exercise: days per week walking for at least 10 minutes. ${ }^{\mathrm{d}}$ Alcohol consumption: if the subject has consumed alcohol twice or more times a month over the last year.

Abbreviations: COPD, chronic obstructive pulmonary disease; EHSS, European Health Interview Surveys for Spain.

Table S2 Multivariable model to assess variables associated to health and home care services use among Spanish COPD subjects included in the EHSS 2009

\begin{tabular}{|c|c|c|c|c|}
\hline Variables & $\begin{array}{l}\text { Hospitalization, } \\
\text { OR }(95 \% \mathrm{Cl})\end{array}$ & $\begin{array}{l}\text { General practitioner } \\
\text { visit, OR }(95 \% \mathrm{Cl})\end{array}$ & $\begin{array}{l}\text { Non-general practitioner } \\
\text { services use, OR }(95 \% \mathrm{CI})\end{array}$ & $\begin{array}{l}\text { Home care services } \\
\text { use, OR }(95 \% \mathrm{Cl})\end{array}$ \\
\hline \multicolumn{5}{|l|}{ Gender } \\
\hline Men & I & I & I & 1 \\
\hline Women & $0.67(0.42-1.07)$ & $1.05(0.72-1.52)$ & $0.99(0.75-1.46)$ & $\mathrm{I} .44(0.75-5.76)$ \\
\hline \multicolumn{5}{|l|}{ Age groups } \\
\hline $40-54$ years & I & I & I & 1 \\
\hline $55-69$ years & $1.08(0.60-1.65)$ & $1.70(1.09-2.65)$ & $0.84(0.54-\mid .3 \mathrm{I})$ & $0.81(0.30-2.17)$ \\
\hline 70 years or over & $1.95(1.08-3.53)$ & $3.18(1.98-5.11)$ & $0.68(0.42-1.09)$ & $4.02(1.59-10.20)$ \\
\hline \multicolumn{5}{|l|}{ Monthly income } \\
\hline$<850$ Euros & & & I & 1 \\
\hline $850-1,400$ Euros & & & $1.40(0.94-2.08)$ & $1.22(0.77-2.07)$ \\
\hline$>1,400$ Euros & & & $1.55(1.03-2.31)$ & $0.94(0.49-1.65)$ \\
\hline \multicolumn{5}{|l|}{ Living with partner } \\
\hline Yes & & I & & 1 \\
\hline No & & $0.65(0.47-0.90)$ & & $1.82(1.12-2.97)$ \\
\hline \multicolumn{5}{|l|}{ Self-rated health } \\
\hline Very good/good & 1 & 1 & & 1 \\
\hline Fair/poor/very poor & $2.85(1.62-5.02)$ & $1.56(1.08-1.82)$ & & $2.72(1.13-6.56)$ \\
\hline \multicolumn{5}{|l|}{ Any chronic comorbidity } \\
\hline No & I & I & & 1 \\
\hline Yes & $1.62(1.10-2.36)$ & $1.52(1.12-2.07)$ & & $2.57(I .48-4.43)$ \\
\hline \multicolumn{5}{|l|}{ Mental disorder } \\
\hline No & I & 1 & $1.82(1.28-2.59)$ & I \\
\hline Yes & $1.92(1.24-2.88)$ & $1.49(1.03-2.17)$ & & $1.93(1.17-3.19)$ \\
\hline \multicolumn{5}{|l|}{ High blood pressure } \\
\hline No & & 1 & & \\
\hline Yes & & $1.40(1.03-1.94)$ & & \\
\hline \multicolumn{5}{|l|}{ Pain } \\
\hline No & & 1 & I & \\
\hline Yes & & $2.13(1.52-2.97)$ & $2.07(1.43-2.99)$ & \\
\hline \multicolumn{5}{|l|}{ Body mass index } \\
\hline$<25 \mathrm{~kg} / \mathrm{m}^{2}$ & & I & & \\
\hline $25-30 \mathrm{~kg} / \mathrm{m}^{2}$ & & $0.77(0.54-I . I I)$ & & \\
\hline$\geq 30 \mathrm{~kg} / \mathrm{m}^{2}$ & & $0.62(0.4 \mathrm{I}-0.92)$ & & \\
\hline \multicolumn{5}{|l|}{ Physical exercise } \\
\hline 0-3 days per week & & & & 1 \\
\hline 4-7 days per week & & & & $0.42(0.26-0.66)$ \\
\hline \multicolumn{5}{|l|}{ Alcohol consumption } \\
\hline No & & & & 1 \\
\hline Yes & & & & $0.36(0.19-0.677)$ \\
\hline
\end{tabular}

Abbreviations: COPD, chronic obstructive pulmonary disease; EHSS, European Health Interview Surveys for Spain. 
Table S3 Multivariable model to assess variables associated to health and home care services use among Spanish COPD subjects included in the EHSS 2014

\begin{tabular}{|c|c|c|c|c|}
\hline Variables & $\begin{array}{l}\text { Hospitalization, } \\
\text { OR }(95 \% \mathrm{Cl})\end{array}$ & $\begin{array}{l}\text { General practitioner } \\
\text { visit, OR }(95 \% \mathrm{Cl})\end{array}$ & $\begin{array}{l}\text { Non-general practitioner } \\
\text { services use, OR }(95 \% \mathrm{Cl})\end{array}$ & $\begin{array}{l}\text { Home care services } \\
\text { use, OR }(95 \% \mathrm{Cl})\end{array}$ \\
\hline \multicolumn{5}{|l|}{ Gender } \\
\hline Men & I & I & 1 & 1 \\
\hline Women & $1.21(0.74-0.95)$ & $0.82(0.54-1.22)$ & $1.32(0.89-1.97)$ & $\mathrm{I} .44(0.75-2.69)$ \\
\hline \multicolumn{5}{|l|}{ Age groups } \\
\hline 40-54 years & I & I & 1 & I \\
\hline $55-69$ years & I.9I (0.98-3,075) & $\mathrm{I} .47(0.88-2.4 \mathrm{I})$ & $0.79(0.48-1.32)$ & I.37 (0.47-4.04) \\
\hline 70 years or over & $2.71(1.34-5.50)$ & $1.48(0.86-2.54)$ & $0.84(0.49-1.44)$ & $4.25(\mid .47-12.31)$ \\
\hline \multicolumn{5}{|l|}{ Monthly income } \\
\hline$<850$ Euros & & 1 & & I \\
\hline $850-1,400$ Euros & & $1.22(0.81-1.83)$ & & $0.60(0.35-1.03)$ \\
\hline$>1,400$ Euros & & $0.58(0.39-0.87)$ & & $0.47(0.26-0.88)$ \\
\hline \multicolumn{5}{|l|}{ Living with partner } \\
\hline \multicolumn{5}{|l|}{ Yes } \\
\hline \multicolumn{5}{|l|}{ No } \\
\hline \multicolumn{5}{|l|}{ Self-rated health } \\
\hline Very good/good & I & & & I \\
\hline Fair/poor/very poor & $2.75(1.58-4.79)$ & & & $2.48(I .18-5.2 I)$ \\
\hline \multicolumn{5}{|c|}{ Any chronic comorbidity } \\
\hline No & I & & & \\
\hline Yes & $1.70(1.12-2.58)$ & & & \\
\hline \multicolumn{5}{|l|}{ Mental disorder } \\
\hline No & & & 1 & \\
\hline Yes & & & $1.95(1.36-2.80)$ & \\
\hline \multicolumn{5}{|l|}{ High blood pressure } \\
\hline No & & 1 & & \\
\hline Yes & & $1.69(1.23-2.33)$ & & \\
\hline \multicolumn{5}{|l|}{ Pain } \\
\hline No & & 1 & & \\
\hline Yes & & $1.58(1.07-2.32)$ & & \\
\hline \multicolumn{5}{|l|}{ Body mass index } \\
\hline$<25 \mathrm{~kg} / \mathrm{m}^{2}$ & & I & & \\
\hline \multicolumn{5}{|l|}{$25-30 \mathrm{~kg} / \mathrm{m}^{2}$} \\
\hline \multicolumn{5}{|l|}{$\geq 30 \mathrm{~kg} / \mathrm{m}^{2}$} \\
\hline \multicolumn{5}{|l|}{ Physical exercise } \\
\hline 0-3 days per week & I & & & I \\
\hline 4-7 days per week & $0.61(0.42-0.86)$ & & & $0.37(0.25-0.57)$ \\
\hline \multicolumn{5}{|l|}{ Alcohol consumption } \\
\hline No & & 1 & & \\
\hline Yes & & $0.54(0.38-0.77)$ & & \\
\hline
\end{tabular}

Abbreviations: COPD, chronic obstructive pulmonary disease; EHSS, European Health Interview Surveys for Spain. 
Table S4 Sensitivity analysis. Multivariable model to assess variables associated to health and home care services use among Spanish COPD subjects included in the EHSS 2009 and 2014 excluding monthly income

\begin{tabular}{|c|c|c|c|c|}
\hline Variables & $\begin{array}{l}\text { Hospitalization, } \\
\text { OR }(95 \% \mathrm{Cl})\end{array}$ & $\begin{array}{l}\text { General practitioner } \\
\text { visit, OR }(95 \% \mathrm{Cl})\end{array}$ & $\begin{array}{l}\text { Non-general practitioner } \\
\text { services use, OR }(95 \% \mathrm{Cl})\end{array}$ & $\begin{array}{l}\text { Home care services } \\
\text { use, OR }(95 \% \mathrm{Cl})\end{array}$ \\
\hline \multicolumn{5}{|l|}{ Gender } \\
\hline Men & I & 1 & I & 1 \\
\hline Women & $0.85(0.6 \mathrm{I}-\mathrm{I} .13)$ & $0.96(0.75-1.24)$ & $1.13(0.88-1.46)$ & $1.45(0.96-2.21)$ \\
\hline \multicolumn{5}{|l|}{ Age groups } \\
\hline $40-54$ years & I & 1 & $\mathrm{I}$ & 1 \\
\hline $55-69$ years & $1.35(0.90-2.01)$ & $1.55(1.15-2.08)$ & $0.85(0.63-1.16)$ & $0.99(0.48-1.77)$ \\
\hline 70 years or over & $1.99(1.32-3.00)$ & $2.04(1.48-2.79)$ & $0.72(0.52-0.99)$ & $3.46(1.08-6.45)$ \\
\hline \multicolumn{5}{|l|}{ Living with partner } \\
\hline Yes & & 1 & & 1 \\
\hline No & & $0.79(0.64-0.97)$ & & $1.55(1.15-2.10)$ \\
\hline \multicolumn{5}{|l|}{ Self-rated health } \\
\hline Very good/good & I & I & & 1 \\
\hline Fair/poor/very poor & $2.7 \mid(1.89-3.89)$ & $\mathrm{I} .4 \mathrm{I}(\mathrm{I} .10-1.8 \mathrm{I})$ & & $2.21(1.34-3.66)$ \\
\hline \multicolumn{5}{|l|}{ Any chronic comorbidity } \\
\hline No & I & 1 & 1 & 1 \\
\hline Yes & $1.75(1.35-2.27)$ & $1.39(1.14-1.72)$ & $1.19(1.01-1.49)$ & $1.73(1.23-2.43)$ \\
\hline \multicolumn{5}{|l|}{ Mental disorder } \\
\hline No & I & I & I & 1 \\
\hline Yes & $1.26(0.97-1.64)$ & $1.34(1.05-1.7 I)$ & $1.97(1.57-2.49)$ & $1.60(1.16-2.21)$ \\
\hline \multicolumn{5}{|l|}{ High blood pressure } \\
\hline No & & 1 & & \\
\hline Yes & & $1.57(1.28-1.92)$ & & \\
\hline \multicolumn{5}{|l|}{ Pain } \\
\hline No & & 1 & I & \\
\hline Yes & & $1.90(1.51-2.39)$ & $1.58(1.24-2.02)$ & \\
\hline \multicolumn{5}{|l|}{ Body mass index } \\
\hline$<25 \mathrm{~kg} / \mathrm{m}^{2}$ & & I & & \\
\hline $25-30 \mathrm{~kg} / \mathrm{m}^{2}$ & & $1.06(0.84-1.34)$ & & \\
\hline$\geq 30 \mathrm{~kg} / \mathrm{m}^{2}$ & & $0.83(0.62-0.99)$ & & \\
\hline \multicolumn{5}{|l|}{ Physical exercise } \\
\hline $0-3$ days per week & I & & & 1 \\
\hline 4-7 days per week & $0.78(0.62-0.98)$ & & & $0.44(0.30-0.55)$ \\
\hline \multicolumn{5}{|l|}{ Alcohol consumption } \\
\hline No & & I & & I \\
\hline Yes & & $0.68(0.54-0.84)$ & & $0.62(0.44-0.89)$ \\
\hline \multicolumn{5}{|l|}{ EHSS } \\
\hline 2009 & I & 1 & 1 & 1 \\
\hline 2014 & $\mathrm{I} .04(0.82-|.3|)$ & $0.87(0.72-1.07)$ & $1.29(1.05-1.57)$ & $1.15(0.86-1.53)$ \\
\hline
\end{tabular}

Abbreviations: COPD, chronic obstructive pulmonary disease; EHSS, European Health Interview Surveys for Spain.

\section{Publish your work in this journal}

The International Journal of COPD is an international, peer-reviewed journal of therapeutics and pharmacology focusing on concise rapid reporting of clinical studies and reviews in COPD. Special focus is given to the pathophysiological processes underlying the disease, intervention programs, patient focused education, and self management protocols.

\section{Dovepress}

This journal is indexed on PubMed Central, MedLine and CAS. The manuscript management system is completely online and includes a very quick and fair peer-review system, which is all easy to use. Visit http://www.dovepress.com/testimonials.php to read real quotes from published authors. 